\title{
TAXATION OF RETIREMENT PROVISION
}

\author{
RICHARD L. STRECKER*
}

The cessation of remunerative employment inevitably results in a reduction of income if not its entire elimination. Among our 16.6 million persons over age $65,{ }^{1}$ three-fifths have annual money income not exceeding $\$ 1,000 .{ }^{2}$ While the average income of this group is no doubt increasing, it is not clear whether the increase will do more than offset the declining purchasing power of the dollar. Our present federal tax laws extend a number of benefits to persons over age 65 in recognition of the special problems which aging presents.

\section{I}

Present Tax Benefits to the Aging

\section{A. Doubled Personal Exemptions}

For the year in which a taxpayer attains age 65 and thereafter, he is entitled to an additional income tax exemption of $\$ 600$, and can thus receive $\$ \mathrm{r}, 200$ without any tax liability whatever. ${ }^{3}$ Indeed, one so situated need not even file a Federal Income Tax Return. ${ }^{4}$ If both husband and wife have reached 65 , the couple may receive $\$ 2,400$ free of tax. The effect of this provision alone appears to eliminate perhaps as much as four-fifths ${ }^{5}$ of our aged population from contributing to the federal fisc via the income tax. If persons of this income level over age 65 should be removed from the taxable category by reason of inability to pay, does not the same inability indicate that all persons with income not exceeding $\$ \mathrm{x}, 200$ should be outside the income tax sphere? A proposal to increase personal exemptions of all taxpayers to $\$ 1,200$ would certainly encounter opposition since it would entail a large revenue loss. But the suggestion reveals the degree to which the present provision favors one class of taxpayers over another similarily situated.

\section{B. Liberalized Medical Expense Deduction}

Generally, only extraordinary medical expenses-the amount in excess of three per cent of adjusted gross income-can be deducted. Since 1958, persons over age

- A.B. 1947, LL.B. x950, University of Cincinnati; LL.M. x95x, Harvard University. Professor of Law, University of Cincinnati. Member of the Ohio bar.

${ }^{2}$ See 1960 Censtls, U.S. Bureat of the Census, Dep't of Commerce, Statistical Abstract of THE UNITED StATES 26 (I96I).

${ }^{3}$ See statement of Professor Wilbur J. Cohen, House Comm. on Ways and Means, Income Tax Revision-Panei Discussions on Revision of the Federal Income Tax Structure, 86th Cong., ist SEss. 243, 244 (1959). The proportion is based on 1957 data, and may possibly have changed since then. The Census Bureau's analysis for 1960 is not yet available. For 1960, the median income of persons over age 65 who had income was $\$ 1,076$. See U.S. BurEAU of THE CENsus, op. cit. supra note $x$, at 266 .

${ }^{3}$ INT. Rev. Code of I954, $\$$ ISI (c) [hereinafter cited as Code].

Id. \$6012(a)(x).

"House Comms. on Ways and Means, op. cit. supra note 2. Professor Cohen states that for $19574 / 5$ of persons over age 65 had income not exceeding $\$ 2,000$. Id. at 244 . 
${ }_{6}$ have been entitled to deduct all medical and dental expenses, those falling below as well as above three per cent of adjusted gross income. ${ }^{8}$ This treatment is in recognition of the increasing medical expenses to which older persons are subject. However, to the extent that aged persons typically experience higher medical costs, they are likely to be able to meet the three per cent requirement. Given the same income, should a person over 65 be entitled to deduct routine medical expense under three per cent of adjusted gross income, while his younger fellow citizen cannot?

It has been urged that the critical problem involves persons who either cannot afford to pay for medical service at the going rate or whose income is so small that they would pay little if any tax even without the benefit of the medical expense deduction. ${ }^{7}$ It is desirable to recognize the burden of increasing medical expense of aging persons. The present trend towards health insurance might be encouraged by relieving the three per cent requirement for taxpayers of all ages as to amounts paid for health insurance premiums. The important deficiency in private insurance plans seems to be the inadequate spreading of the risk of high medical expense which comes in advanced years over the earlier working years. Such a deduction could be limited to premiums paid on health insurance which was non-cancellable by reason of age. It would be an important policy decision to favor insurance funding of this liability as against current cash payment by the individual of the actual experienced expense. The impact which unusually large medical and hospitalization expense can have upon the economic well-being of persons of limited income indicates the social desirability of insurance funding. The maintenance of a vigorous and independent medical profession might be enhanced by a broadened program of private voluntary insurance. The same end could be encouraged by limiting the employer's deduction to amounts paid as premiums on non-cancellable policies-lifetime health insurance.

\section{Social Security and Retirement Income Credit}

The employer's contribution to the cost of Old Age and Survivors Disability Insurance under the Social Security law (which in 1962 will amount to $31 / 8$ per cent of wages and salaries) ${ }^{8}$ is not included in the employee's income for tax purposes. The corresponding employee's contribution is not deductible by him and hence is paid out of taxable income. ${ }^{9}$ The benefits are entirely free of income tax when received $^{10}$ even though only the employee's contribution thereto has previously been subject to taxation. The portion of the benefits which arises from the employer's contribution, the portion which arises from the interest earned on the Social Security trust fund, and the portion (if any) which might arise from the general revenues

\footnotetext{
${ }^{\circ}$ CoDe $\$ 213$. Effective after 1960 , this section also relieves the $3 \%$ rule as to payments made or behalf of a dependent mother or father over 65 .

${ }^{7}$ See statement of Dr. Eveline M. Burns, in House Comm. on Ways and MEans, op. cit. supra note 2 , at 258,260 .

${ }^{8}$ CoDE $\S 3$ III.

'Id. \$§ 3101, $164(\mathrm{~b})(\mathrm{I})(\mathrm{A}), 3502(\mathrm{a})$.

${ }^{10}$ I. T. 3447. I94I-I CuM. BuLl. I9I.
} 
of the Treasury Department are never subject to tax. Undoubtedly, a major reason for this was the fact that the benefits are relatively small (although increasing in recent years). What is sometimes overlooked is the fact that a person over age 65 receiving Social Security under present law also is entitled to an exemption of $\$ 1,200 .^{11}$ Thus under the present law a married couple could receive maximum Social Security benefits of $\$ 1,524 .^{12}$ and additional outside income from investments of $\$ 2,400$ without becoming subject to the Federal Income Tax. Because of the ten per cent optional standard deduction, ${ }^{13}$ more than $\$ 200$ additional could be received and yet no tax liability would arise. Is it necessary or desirable to excuse from Federal Income Tax liability married couples whose total income exceeds $\$ 4,000$ ?

One who is under the Social Security law by virtue of the self-employment tax will also receive all benefits tax free. The benefits will be the same despite the fact that the total contribution on behalf of the self-employed person is considerably less than the combined contribution of the employer and employee. ${ }^{14}$ One reason for this might be the fact that self-employment income may include some return on capital investment in a proprietorship or partnership business as well as earnings from personal effort. Tax equity, however, has not been achieved. The entire contribution made by the self-employed contributor comes out of taxable income $\mathrm{e}^{15}$ whereas only one-half of the contribution made for employees is included in the tax base.

The inequity between persons receiving tax free Social Security benefits and those who have provided for their retirement through private pension plans or voluntary individual savings is apparent. In the major tax revision of 1954, Congress attempted to achieve tax parity by giving to the latter class of taxpayers the tax benefit theretofore received by the former. The Retirement Income Credit ${ }^{16}$ relieves from taxation, to the extent of the twenty per cent first bracket rate, amounts of investment income received by retired persons up to $\$ \mathrm{r}, 200$ (what was then the maximum Social Security retirement benefit). Any Social Security received by the retired person would offset "retirement income" and thus would reduce or eliminate the credit. By analogy to Social Security, earned income in excess of $\$ 1,200$ offsets the "retirement income," so that $\$ 2,400$ of earned income would eliminate the credit entirely.

On September 27, Ig6I, H.R. 637I was approved by the House of Representatives. The imminent adjournment of Congress prevented this measure from becoming

\footnotetext{
"Note that under present Social Security law retirement payments (althougi lower) may begin at age 62. 64 Stat. 492 (1950), as amended, 42 U.S.C. $\$ 416$ (a) (1958).

${ }^{12} 64$ Stat. 492 (1950), as amended, 42 U.S.C. $\$ 415(\mathrm{a})$, col. IV (I958).

${ }^{13}$ Code $\$ \S 141,3,63(\mathrm{~b})$.

${ }^{31}$ The self-employment tax is approximately one and one-half times the employee's social security tax, and thus three-fourths the amount of combined employer-employee tax. CoDE $\$$ r $40 \mathrm{I}$ imposes the self-employment tax at $4.7 \%$ for 1962 . For the same year, the employee and employer each pay $3 \frac{1 \%}{1 \%}$ or a total of $6 \frac{1}{4} \%$. CODE $\$ 3 I I x$.

${ }^{25}$ The self-employment tax is a kind of federal income tax and hence non-deductible by CODE $\S 16_{4}(b)(I)$.

${ }^{10}$ CODE $\$ 37$.
} 
law, although its chances of passage in 1962 would appear good. Its primary purpose would be to raise the retirement income ceiling to $\$ 1,524$, the present maximum Social Security benefit. It would also modify the earned income rule so that the earned income from $\$ 1,200-\$ 1,700$, the first $\$ 500$ over the permitted amount, would offset retirement income only to the extent of one-half of the amount of income earned. Space limitations preclude a detailed discussion of the almost unbelievable intricacies of section 37 of the Code which deals with the Retirement Income Credit. Suffice it to say that its already abundant complexities would be further enhanced by the proposed changes.

Complicating the tax law enormously, section 37 is understood by only a few retired persons subject to it. Probably many fail to receive its benefits because they file a simple return form which operates to waive the benefit. ${ }^{17}$ Some who even file Form ro4o are totally mystified by the schedule that is devoted to computation of this credit. And yet, even if fully utilized, the provision does not achieve its egalitarian purpose. The total exemption of Social Security benefits may benefit a highbracket recipient to an extent much larger than twenty per cent, while the credit device used limits the benefits to those which would be achieved by a low bracket taxpayer. The remedy is not to exclude retirement income altogether. The answer may be to tax the proceeds of Social Security, allowing a corresponding deduction to the employee or self-employed for his contribution to the cost.

\section{Deferred Compensation}

"Deferred compensation" in a general sense may describe any arrangement whereby the realization of compensation for personal service is postponed to a taxable year different from that during which the service was rendered. Greater tax favor is accorded to "Qualified" plans, characterized by broad diffusion of the benefits of the plan among the employees of a particular business enterprise.

\section{(I) Advantages of the Qualified Plan}

(a) Employee Deferral. The employer's contributions to the plan are not currently taxable to the employee. ${ }^{18}$ Benefits, when received by the employee, are taxable except to the extent that each payment represents a return of the employee's previously taxed contributions to the plan. The aggregate of employee contributions constitutes his "investment in the contract" for the purposes of the annuity rule. If the employee's contributions are relatively minor so that their amount would be recovered within the first three years of retirement, benefits are excluded entirely from the employee's income until his contributions have been recovered tax-free, whereupon all subsequent payments are fully taxable. Where the employee's contributions are relatively larger, the ratio between the investment in the contract and the "expected return" is mathematically calculated. (The expected return is computed by multiplying the annual annuity payment by the

${ }^{17} I d$. $\$ \$ 37$ (i), 6014(a).

${ }^{18} I d . \$ \$ 402(\mathrm{a})(\mathrm{I}), 403(\mathrm{a})(\mathrm{I})$. 
life expectancy of the annuitant at the retirement date.) Thus, the proportion of each payment which represents the return of the employee's capital investment is excluded from income, and only the remaining portion of each payment constitutes gross income for tax purposes. This proportionate exclusion is available to the annuitant for so long as he may live, even though he may outlive his life expectancy and thus exclude more from income than the amount of his actual investment. ${ }^{19}$

Deferral offers many subsidiary tax advantages: (r) The decline in income which accompanies retirement places retirement income in lower tax brackets. (2) Personal exemptions are doubled, and $\$ 1200-\$ 2400$ per year will be in the zero tax bracket. (3) Not only is the investment portion of retirement annuities exempt, but even the "taxable" portion of retirement income from investment sources up to $\$ 1200$ per year, via the retirement income credit, is exempt from tax up to the twenty per cent first bracket rate. (4) In recognition of the inequitably high brackets which would apply if the employer's contribution to a qualified plan were paid to the employee in a lump sum rather than an annuity, capital gain treatment was extended to such payments in $19544^{20}$ For persons whose income even in retirement is relatively high, election of lump sum distribution may prove highly beneficial. (5) Postponement of tax payment gives the employee the benefit of the use of the "tax" funds in the interim, thus enhancing the retirement provision by the increment on the funds which would otherwise have been paid to the Government in prior years.

(b) Employer Deduction. The employer's contributions to the plan are deductible when made, ${ }^{21}$ even though this might appear inconsistent with deferral of the employee's taxation. We encounter here a true "taxpayer's friend"-both the employee and the employer receive the most favorable tax timing without endangering the status of the other.

(c) Accumulation on Fund. The increment on funds set aside for retirement accumulates tax-free. ${ }^{22}$ Instances are rare in which funds may become compounded without the interposition of income tax reducing the net increment. The accumulation on the fund, if applied to enhance retirement benefits, will reach the employee's tax return eventually, subject to enhanced taxation. More realistically, the tax free accrual is applied to reduce the employer's cost, rendering a plan more feasible. Of course, the employee will receive more benefits than a given employer contribution would yield absent this factor. Until 1959, tax-free accumulation was an advantage uniquely available to trusteed plans. Since the funds provided for insured plans were committed to the insurance companies, the earnings which they produced were taxable in the same manner as any other insurance company income from a like source. In 1959, the tax law was amended so as to exempt insurance com-

${ }^{20}$ Id. $\S 72$.

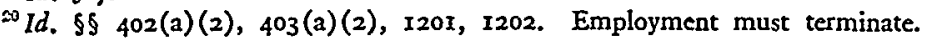

IId. 5404 .

2Id. \$\$ $501(\mathrm{a}), 501(\mathrm{c})(17)$. 
panies from income tax with respect to earnings produced by funds set aside for qualified plans. ${ }^{23}$ Thus, insurance companies are able to provide higher total benefits for the same cost, or the former total benefits for a lower cost than formerly, and are placed in an approximately equal competitive position with banks and trust companies for the lucrative pension plan business.

(d) Estate Tax. The portion of annuity death benefits attributable to the employer's contributions is excluded from the employee's gross estate. ${ }^{24}$ If an employee had a vested contractual right to designate the recipient of death benefits such amounts were considered property owned by the decedent and hence were taxable under the 1939 Code. $^{25}$ Otherwise, death benefits paid under totally noncontributory plans escaped estate taxation because there was no "transfer" by the decedent. $^{26}$ The 1954 Code eliminates the requirement of a transfer and includes all benefits, whether purchased by decedent's contributions or by those of his employer, reserving favorable treatment for that portion of the benefits which is attributable to the employer's contribution to a qualified plan.

(e) Gift Tax. Designation of a beneficiary to receive death benefits under a qualified plan is excluded from the gift tax to the extent of benefits attributable to the employer's contributions. ${ }^{27}$ This special exclusion, introduced in $195^{8}$, does not imply that all other similar transactions were before, or are now, subject to gift tax. Only an irrevocable designation could result in gift tax liability in any event. ${ }^{28}$ Furthermore, the requirement of a "transfer" might preclude imposition of gift tax even as to a non-qualified plan to which the employee made no contributions. ${ }^{20}$

\section{(2) Requirements for Qualification}

When the Revenue Act of 1942 clarified the treatment of pension plans by assuring the income tax advantages mentioned above, availability of these advantages was restricted to those plans which diffused the benefit of retirement provision among the employees of a particular business enterprise. It was decided that these tax advantages should not be conferred on plans the benefits of which were avail-

\footnotetext{
${ }^{23}$ See generally Mayerson, New Tax Law Brings Many Changes to Life Insurance Companies, 13 J. TAXation 71, 73 (1960).

${ }^{2}$ Code $\$ 2039(c)$.

${ }^{2}$ Estate of Garber v. Comm'r, 271 F.2d 97 (3d Cir. 1959), INT. Rev. Code of 1939, $\$ 811(a)$, CODE $§ 2033$.

${ }^{30}$ Nothing is includible under Code $\S 2033$ as property owned at death: Dimock v. Corwin, 19 F. Supp. 56 (E.D. N.Y. 1937), aff'd on other isstes, 99 F.2d 799 (2d Cir. 1938), 306 U. S. 363 (1939); Estate of Salt v. Comm'r, I7 T.C. 92 (195I); contra, G.C.M. 27,242, 1952-1 CuM. But.l. I60; since no transfer, nothing includible under other sections prior to enactment of $\$ 2039$ in 1954: Estate of Miller v. Comm'r, I4 T.C. 657 (1950); Estate of Haggett v. Comm'r, 14 T.C. 325 (1950); Libbey v. United States, 147 F. Supp. $3^{83}$ (N.D. Calif. r956). Contra, Adeline S. Davis v. Comm'r, 27 T.C. 378 (1956). See also Commissioner v. Estate of Twogood, 15 T.C. 989 (1950), aff'd, 194 F.2d 627 (2d Cir. I952); Estate of Higgs v. Comm'r, 184 F.2d 427 (3d Cir. 1950).

${ }^{37}$ CODE $\$ 2517$. Gift Tax Regulations $\$ 25.25 \times 1-1(h)(10)$ (r958) provide that an annuitant's irrevocable election of a joint and survivor annuity is a taxable gift. Adeline S. Davis v. Comm'r, 27 T.C. 378 (1956).

${ }^{28}$ Gift Tax Regulations $\$ 25.251$ 1-2(c)(1958).

$\approx$ See note 26 supra.
} 
able only to top management, whose interest in pension plans was motivated largely by the desire to escape high surtax brackets.

(a) Coverage. Coverage of the plan must include a broad segment of the group of persons employed by a particular business enterprise. The general policy seems to have been to insure participation by a significant plurality of the entire group. The Internal Revenue Code specifically defines this requirement in terms which prohibit discrimination in favor of officers, shareholders, supervisory employees or other highly compensated persons. Three alternative methods of satisfying this requirement are established in the Code..$^{30}$ First, if seventy per cent of all employees (excluding part-time and seasonal employees and those employed less than five years) actually participate in and are benefited by the plan, the requirement is satisfied. Second, if seventy per cent of employees (as defined above) are eligible to benefit, only eighty per cent of these need actually participate in order for the plan to qualify. For illustration, suppose a corporation which employs r,000 persons. Fifty of these are seasonal employees and fifty are part-time employees. One hundred have been employed less than five years. These are excluded altogether for the purpose of the above rules. Under the first alternative, if 560 employees, i.e., seventy per cent of 800 , participate in the plan, it will qualify. The second alternative would require fewer participants. If 560 are eligible, the actual participation of $44^{8}$ employees (eighty per cent of 560 ) would be sufficient to qualify the plan. The less than completely rigorous operation of these rules is illustrated by the fact that in the hypothetical case, less than one-half of the employees participate in the qualified plan. The third alternative is an employer-established classification found by the Internal Revenue Service not to discriminate in favor of officers, shareholders, supervisory employees, or other highly compensated persons. The Code establishes that (I) exclusion of employees receiving only wages of not more than $\$ 4800$ per year (the present maximum amount of wages subject to Social Security tax), and limitation of a plan to (2) salaried or (3) clerical employees will not be deemed discriminatory. ${ }^{31}$ Perhaps the Service would disapprove a plan limited to salaried employees where only stockholder-officers were in the salaried class. ${ }^{32}$ However, the Code language appears mandatory and the Treasury Department has indicated concern about possible abuse in this area. ${ }^{\mathbf{3 3}}$

(b) Benefits. The method of determining the amount of benefits and employer contributions must not discriminate in favor of officers, shareholders, supervisory employees, or other highly compensated persons. ${ }^{34}$ Not only must participation be dispersed among a large segment of the employees, but the substance of this requirement cannot be defeated in the computation of benefits and contributions.

${ }^{\circ 0}$ CODE $\$ 401(a)(3)$.

${ }^{31}$ CODE $\$$ 4Or (a) (5).

32 Leon L. Rice, Jr. \& E. H. Schlaudt, Basic Pension and Propit-Sharing Plans 12 (i957).

${ }^{83}$ Statement of Stanley S. Surrey, Assistant Secretary of the Treasury, before the Senate Finance Committee on H.R. Io, CCH Ig6r Stand. Fed. TAX Rep. $\$ 6472$.

'T CODE $\$$ HOI (2)(4). 
Contributions or benefits which bear a "uniform relationship" to compensation, such as a flat percentage rate applied to all employees (which might be varied according to years of service) ${ }^{35}$ are not discriminatory even though total benefits and contributions will be much larger for highly paid persons. Furthermore, the law permits larger benefits and contributions with respect to wages and salaries in excess of $\$ 4800$ (the maximum amount of "wages" subject to Social Security tax). The Service requires, however, that the plan shall be "integrated with Social Security"meaning that the benefits received with respect to earnings above the Social Security ceiling shall not be proportionately greater than Social Security benefits. ${ }^{36}$

(c) Irretrievability of Employer Contributions. A corollary of the employer deduction for contributions to the plan is that such amounts shall be irretrievably committed to the sole benefit of the employees under the plan, with no chance of reversion to the employer. ${ }^{37}$ This requirement is related to but distinct from socalled "vesting" of the individual employee's rights in the fund. Vesting would prevent the remaining employees from benefiting by the forfeiture which results when a potential beneficiary leaves a particular employer. Present law does not require vesting of an individual employee's rights, ${ }^{38}$ and if there is rapid labor turnover, a non-vested plan may give most of its benefits to the more stable employees including officers, shareholders, supervisory employees, and other highly compensated persons. ${ }^{39}$

\section{(3) Nonqualified Deferred Compensation.}

Nonqualified deferred compensation includes any arrangement for deferral of realization which does not meet the statutory requirements of section 4or, outlined immediately above. The status of such arrangements involves a degree of uncertainty since the Code does not provide an integrated method for their treatment. A few matters are clarified by specific statutes; most must be inferred from general statutory provisions containing broad concepts, and from the "common law" of taxation. To the extent determinable, the present status of nonqualified arrangements will be compared directly with the treatment of qualified plans.

(a) Employee Deferral. A carefully drawn plan can give reasonable assurance that the benefits will not be taxable to the employee at the time of the contract, but will be includible only when actually realized in cash, usually in retirement years. ${ }^{40}$

${ }^{35}$ CODE $\$ 40 I(a)(5)$; RICE \& SchlaUdT, op. cit. supra note 32, at I3.

so Ibid.

${ }^{37}$ CODE $\$ 40 \mathrm{O}(\mathrm{a})(2)$.

${ }^{33}$ Vesting is required of profit sharing plans, but not of pension plans. Rice \& Schlaudr, op. cit. supra note 32 at $\mathrm{I}_{4}$. Forfeiture and shifting would directly benefit other employees under a profit sharing plan. Under a pension plan, forfeiture merely reduces the employer's cost, thus making possible greater benefits and indirectly benefiting the steady employees.

${ }^{30}$ Ryan School Retirement Trust v. Comm'r, 24 T.C. 127 (1955).

${ }^{20}$ Rev. Rul. 60-3I, 1960-r Cum. Bull. 512. Appert, Contingencies in Deferred Compensation Agreements May Still Be a Wise Precaution, I3 J. TAxation I2 (1960); Axelrad, Deferred Compensation Arrangements and Constructive Receipt of Income: Rev. Rul. 60-31, 35 Los ANGeles Bar Bull. 149 (1960); Gordon, New Look of Deferred Compensation Contracts, Io TuL. TAX INST. 593 (1961); Note, I3 J. TAxation 180 (1960); Note, 43 Mare. L. Rev. 389 (1960); Note, Fair Market Value of 
The nonqualified arrangement, albeit with a little less certainty, shares this advantage and all resulting subsidiary advantages detailed above (except capital gain treatment of lump sum distribution), with the qualified plan. Since a nonqualified plan is normally non-contributory, all amounts received will be treated as income in retirement years.

(b) Employer Deduction. Amounts paid as pension or deferred compensation to a retired employee are deductible by the employer only in the year of actual payment. ${ }^{41}$ The attractive combination of employee deferment and current employer deduction is withheld from the nonqualified arrangement. If a nonqualified plan is funded, and the individual employee's rights are vested, employer contributions will be taxable to the employee in the year made, and deferral is sacrificed. However, the employer is permitted, consistently with inclusion by the employee, to deduct contributions in the year made. If the plan is funded and the individual employee's rights are forfeitable (for example, upon leaving this particular employment), then the Code inflicts a harsh punishment indeed. Not only is current deductibility denied, but even when the amounts are paid to the employee, they are still not deductible by the employer. In other words, contributions to a funded-non-vested nonqualified plan are not deductible by the employer at any time. ${ }^{42}$

(c) Accumulation on Fund. Tax-free accumulation on the fund is a key advantage of qualified plans not available to others. As indicated above, any kind of funding of a nonqualified plan is discouraged by present law. There is no provision in present law for the exemption of nonqualified employee trusts, as there is for qualified employee trusts under section 501 (c) (I7). Of course, an employer could set aside investment funds in tax exempt securities, ${ }^{43}$ provided these were not irretrievably committed to the benefit of employees or of a particular employee. $^{44}$ However, the income from such investments would be non-taxable regardless of the purpose for which they were acquired and regardless of by whom they were purchased. The tax-free accumulation of increment on investments which would normally be taxable is uniquely extended to the qualified plan. Recent discussion has focused upon the possibility of accruing "interest" in favor of an employee with respect to promised deferred compensation-the interest to be added

Deferred Payment Contract Held Includible in Gross Income of Cash Basis Taxpayer in Year of Execution of Contract (Frank Cowden, 32 T.C. No. 73), 59 CouUm. L. Rev. 1237 (1959); Note, 1960 Duke L.J. 436; Rice, New Tax Policy on Deferred Compensation, 59 Mich. L. Rev. $38 \mathrm{I}$ (I96r); Weingarten, Internal Revenue Service Relaxes Rules on Deferred Compensation, io SAN Francisco Brief Case I3 (1960); Wood, Contingencies May Still be a Good Idea in Deferred Compensation Contracts, 12 J. TaXation 210 (I960).

¿CODE $\$ 404(\mathrm{a})(5)$.

"Income Tax Regs. § I.404(a)-I2. Cf. Russell Mfg. Co. v. United States, I75 F. Supp. I59 (Ct.

Cl. 1959); Note, 45 VA. L. REv. 1249 (I959).

${ }^{13}$ CODE $\$ 103$.

"Sce note 42 supra. As to the immunity of the employec from immediate taxation, see Casale $\nabla$. Comm'r, 247 F.2d 440 (2d Cir. I957); Prunier v. Comm'r, 248 F.2d 818 (rst Cir. I957); Sanders v. Fox, 253 F.2d 855 (roth Cir. 1958). 
to the principal sum and paid upon retirement. ${ }^{45}$ One of the examples used by the Internal Revenue Service in its recent Revenue Ruling 60-3I encourages such an arrangement. ${ }^{48}$ Perhaps this device achieves for the employee an advantage analogous to that available under the qualified plan.

(d) Estate Tax. No special estate tax advantages exist with respect to nonqualified arrangements. Under the 1954 Code, any death benefits payable to an annuitant's survivor are includible in the annuitant's gross estate. ${ }^{47}$ This applies not only to purchased annuities but also to annuities the consideration for which was furnished by an employer under a nonqualified plan. Where an employee dying before or after retirement has a contractual right to receive certain payments or to have them paid to his estate or beneficiaries, the value of such rights is includible in his gross estate. ${ }^{48}$ Since death has eliminated the contingency that the employee might change employers or might compete with the employer, it has been held that the valuation of contractual rights for estate tax purposes will not be discounted for these now unreal contingencies. ${ }^{49}$ When the payments are received by the estate or beneficiaries, they will be treated as income in the hands of recipient. ${ }^{60}$ As "income in respect of a decedent," they will be offset by the portion of the estate tax attributable to them. ${ }^{51}$ The only nonqualified item which is immune to the estate tax is a non-contractual death benefit which the employer is not legally obligated to provide. ${ }^{2}$ Even in such cases, where the employee has a "right" to designate the recipient under an established plan, the Internal Revenue Service will press for inclusion in the gross estate. ${ }^{53}$ Some rights to designate beneficiaries might constitute powers of appointment and, if "general," would bring the amounts into the gross estate of the holder. ${ }^{54}$

(e) Gift Tax. There is no special exclusion from gift tax for transactions involving nonqualified deferred compensation arrangements. However, as explained above with respect to qualified plans, it is unlikely that designation of a beneficiary would result in gift tax liability. ${ }^{\mathrm{s}}$

Nonqualified deferred compensation arrangements offer few of the advantages conferred upon qualified plans. While deferral may be available, current employer deduction is not. If current employer deduction is achieved, deferral is not. Tax-

\footnotetext{
4s Appert, supra note 40 , at 13 .

${ }^{40}$ See note 40 supra. The favorable example involved crediting to the employee's account his share of the net profits from investing the amount in the account. One unfavorable example involved the payment of interest and one favorable example eschewed such payment. The Ruling is inconclusive, but Appert argues for favorable treatment of a deferred interest arrangement.

${ }^{47}$ CODE $\$ 2039$.

4s Goodman v. Granger, 243 F.2d 264 (3d Cir. I957). See also case cited supra note 25.

${ }^{2}$ Goodman v. Granger, supra note 48.

${ }^{\mathrm{BO}}$ Code 5 69I(a).

${ }^{51}$ Id. $\$ 6 \mathrm{gr}(\mathrm{c})$.

4 See note 26 supra.

${ }^{23}$ G.C.M. 27,242, 1952-I CuM. BuLL. I60.

H. CODE $\$ 2041$.

$\$$ Election of 2 joint and survivor annuity is the circumstance most likely to invoke gift tax. See note 27 supra.
} 
free accumulation on the fund is not available. Full estate tax includibility may be expected, and no special exemption from gift tax is extended. The balance of convenience strongly favors qualified plans, consistently with the intent of present law. Why, it may be asked, are nonqualified arrangements ever employed by an informed taxpayer's counsel?

The answer may be found in two major considerations. First, the nonqualified arrangement may be employed for the benefit of selected individuals who can command it (even supplementing benefits under a qualified plan) or for the entire class of high-salaried top management personnel. There are no explicit limitations to the discrimination in availability and benefits which may be practiced under these arrangements. ${ }^{56}$ Secondly, nonqualified plans are preferred because they represent a more limited commitment. If an executive agrees that instead of $\$ 50,000$ per year cash salary he will receive $\$ 30,000$ currently and the remaining $\$ 20,000$ spread over the years from age $\sigma_{5}$ to age 75 , the employer has undertaken no more financial commitment than the current payment of the cash salary in question. Indeed, there is an economic advantage in favor of the employer since he has the use of the $\$ 20,000$ in the interim. The initiation of a qualified pension plan involves a major financial undertaking by the employer, the obligation of which may extend far down the avenue of the future. Frequently, the bulk of employees expect that the plan will be entirely supplementary to their regular cash wages, and do not view a retirement provision as the equivalent of a cash wage. (Since many plans are not vested this tendency may be well founded on the part of the more mobile workers).

Added impetus to the employment of nonqualified devices was furnished by the Internal Revenue Service in I960. Its long-awaited Revenue Ruling 60-3 $\mathrm{r}^{57}$ clarified a number of theretofore uncertain questions. Prior to I960, counsel drafting nonqualified arrangements were concerned that the doctrine of "constructive receipt" or the related "economic benefit" concept might be applied to hold that a contractual right to receive future payment is income to the employee at the time the services are rendered and the contract is made. In a workmanlike endeavor to ward off this danger, they drew such contracts so as to make ultimate receipt contingent on a number of events which would be resolved only at some remote future time. Specifically, it was common to make ultimate payment contingent upon the employee's remaining in the employ of the particular business enterprise. This contingency in the "work out" period was thought effective to prevent inclusion during the duration of the employment period. One writer suggested that the attainment of retirement age would eliminate this contingency, and might cause all retirement income to be accrued in the year of retirement. ${ }^{58}$ In order to avoid this

\footnotetext{
1. ${ }^{* 0}$ Of course, the aggregate compensation, cash and deferred, must be reasonable. CoDE $\S 162(\mathrm{a})(\mathrm{I})$, Income Tax Regs. $1.162-7$ (1958). This requirement limits qualified as well as nonqualified arrangements. RICE \& SCILAUDT, op. cit. supra note 32 , at 16 ..

${ }^{67} \mathrm{Sec}$ note 40 stspra.

Es Eisenstein, $A$ Case of Deferred Compensation, 4 TAX L. REv. $39 \mathrm{I}$ (I949)...
} 
possibility, further contingencies for the "pay out" period were commonly employed. Most frequent was the requirement that, after retirement, the employee not compete with his former employer. The agreement would provide that if he did compete, he would thereby forfeit his right to future payments. Finally, continued receipt of the payments was made contingent upon the rendition of consulting services when requested by the former employer. (If consulting services are to be given only upon demand, they may reduce or eliminate Social Security benefits only for a particular month). ${ }^{59}$

The most significant change introduced by the new Revenue Ruling is to make it clear that contingencies such as those enumerated above, whether real or fictitious in the actual fact situation, were in any event unnecessary to secure the advantage of deferral. Several cautious commentators, remembering former reversals of Treasury views, would retain the full panoply of appropriate contingencies in contracts drawn for their clients. ${ }^{80}$ Perhaps also many employers will wish to continue the practice of tying the employee to them with a silver cord of contingent deferred compensation. Surely no astute employee would accept, as a substitute for cash of an equal amount, deferred compensation whose ultimate receipt depended on his own immobility. But where such agreements are used more to season the pot of total job advantages, such contingencies will still be employed for a business or commercial reason. Where the contingencies were unreal in the factual situation presented, nothing would be gained by elimination of these contingencies in future contracts. But in that middle ground where the contingencies would have real meaning and the employee is bargaining for deferred compensation to sweeten his tax position, it seems likely that contingencies will recede in importance and tend to disappear in practice.

The second major point clarified by Revenue Ruling 60-3r relates to funding. As mentioned above, funding jeopardizes either deferral or employer deductibility, depending upon whether the individual employee's rights are vested. ${ }^{61}$ The new Revenue Ruling 60-3r lends further emphasis to the undesirability of funding a nonqualified plan, if further emphasis were needed. Clear warning is extended that placing the funds in trust or in escrow to assure ultimate payment to the employee will bring about immediate inclusion in the employee's income. This is not to say that an employer cannot, in a different sense, "fund" his anticipated obligation. So long as the funds set aside to meet the liability under the deferred compensation arrangement remain the property of the employer and would be available to satisfy creditors' claims against the employer, the advantage of deferral is not in jeopardy.

${ }^{50} 74$ Stat. 936 ( 1960$)$, 42 U.S.C. $\$ 403(b), 403(f)(I)(D)$ and $403(f)(4)$ (Supp. II 1961). Consulting services may prevent termination of employment and hence jeopardize capital gain treatment for lump-sum distributions from qualified plans. See note 20 supra.

${ }^{\infty}$ See Appert, supra note 40; Wood, supra note 40.

${ }^{\circ}$ See note 42 supra and related text. 
(4) The Plight of the Self-Employed: H.R. Io

Since I95I, a rising crescendo of complaint has emanated from the self-employed. ${ }^{22}$ Most vocal has been the professional man, whose earnings may place him in a relatively high bracket but who must provide for retirement out of after-tax earnings. He eyes covetously his corporate executive neighbor of similar income who looks forward to relative financial security for old age under a qualified plan. At least for the self-employed who do intend to retire, a real inequity exists, although it affects those employed by a proprietorship or partnership as well as the proprietors themselves. The effect upon these employees is indirect but nonetheless real. Since their employers cannot themselves qualify as "employees" and gain the benefits of a qualified plan, the incentive which has served so well to stimulate the growth of qualified plans is lacking. Perhaps the most natural response in the face of envy is to seek for oneself the coveted advantage. And this is the wellworn but as yet unsuccessful path trodden by the self-employed since I95I. The perennial H.R. Io offers tax reform the American way: "Give the same loophole to everyone." (If this goal were truly attained, it would result in a highly equitable and perhaps psychologically more acceptable tax system.)

Immediately before adjournment in September Ig6I, Congress came near to passing H.R. ro. The bill had been approved by the House of Representatives, and had been reported favorably to the Senate by the Committee on Finance. The essence of the bill is the allowance of a deduction for amounts of self-employment income set aside irretrievably to provide for future retirement. The annual deduction would be limited to ten per cent of earned income (excluding return on capital investment in the business), subject to a maximum ceiling; of $\$ 175^{\circ}$ per year. The entire amount set aside up to $\$$ Iooo, but only one-half of the excess, would be deductible, up to a maximum of $\$ 2500$ (for earned income of $\$ 25,000$ or more). Thus, if earned income equaled $\$ 25,000$, ten per cent or $\$ 2500$ could be set aside for retirement. The first $\$ 1000$ plus $\$ 75^{\circ}$ (one-half of the added $\$ 1500$ ) would be deductible.

A number of objections to the bill as approved by the House were overcome by amendments made in the Senate Finance Committee; others were not.

(a) The House bill required the self-employed to include their employees in a plan only if there were four or more employees. This was attacked as discriminatory against the persons employed in a group of less than four employees. It was

Donohue, Smathers-Keogh-Simpson Legislation: Retirement Savings for the Self-Employed, 45 A.B.A.J. 795 (1959); Jones \& Boehm, Keogh Reviesv: Highlights of the Efforts to Secure Tax Relief for Retirement Savings of the Self-Employed, I4 J. Am. Soc'y C.L.U. Ior (1960); Keogh, Pensions for the Self-Employed: Passage of New H.R. 10 is Indicated, I00 Trusts \& Estates I75 (r961); Keogh, Tax Equity for Self-Employed, 47 A.B.A.J. 655 (I96I); Lauritzen, Self-Employed TaxpayerSecond Class Citizen, 4 TAx Counselor's Q. I (x960); Polisher, Self-Employed Individuals' Retirement Bill of 1959, r959 INs. L.J. 309, 37 TAxEs 32I (1959); Rapp, The Jenkins-Keogh Bill-An Explanation, 24 J. BAR Ass'N KAN. 240 (I956); 27 N.Y.STATE BAR BuLL. 424 (1955): Silverson, Taxation and the Self-Employed-A Study of Retrogression, 4I A.B.A.J. 50 (I955); Trigg, The Jenkins-Keogh Bills-What They Mean to the Lawyer, 24 Detrort LAw. 3 (1956); Vernon \& Molloy, Retirement Benefits for the Self-Employed, 12 F.R.D. 417 (1952). 
also characterized as unduly favoring this class of employer as compared with corporate employers of less than four. The Senate bill requires coverage of the $\mathrm{cm}$ ployees of self-employed persons without regard to their number.

(b) Contributions for the employees of self-employed persons would necessarily be based on earned income. The House bill permitted the self-employed to take deductions based on "self-employment income" which would sometimes include a return in the nature of interest on capital invested in the business. Thus, contributions for the self-employed would be computed on a more favorable basis than contributions for their employees. The Senate bill bases all contributions on earned income only, which is defined as thirty per cent of the self-employment income where capital is employed in the business.

(c) Neither bill extended capital gain treatment to lump-sum distributions, thereby failing to achieve tax equity between corporate employees and the selfemployed. While the House bill would have treated such sums as ordinary income in the year of receipt, the Senate bill relieves bunching to a limited extent. The amount received is subjected to a tax equal to five times the amount which would result from including one-fifth of the lump-sum in income in the year of receipt. This is similar to a spreadback, but measures the bracket level by the year of receipt rather than the average income of the five year span.

(d) Both bills required that the employee's rights (as well as those of the selfemployed) should vest at an early point. Since early vesting is not required of qualified pension plans (although it is of profit sharing plans), this may be cited as a discrimination in favor of the self-employed and their employees as against corporate employees.

(e) Since there is no dollar limitation on the amount of contribution which may be made under a qualified plan, tax equity is not achieved by H.R. ro which permits the deduction of the lesser of ten per cent of earned income or $\$ 1750$.

The first two objections to H.R. Io have been cured by the Senate amendments. The third objection calls in question the appropriateness of capital gains treatment under qualified plans, not the validity of the Senate's proposed averaging approach. If equality is to be achieved with respect to lump-sum distributions, it might better be sought on a basis more justifiable than the capital gains approach. If the vesting requirements of the Senate bill discriminate in favor of the self-employed and their employees, the remedy might be to extend the early vesting requirement to qualified plans, not to withhold it from the new proposal. Finally, while H.R. ro does not bring about equality of treatment between the self-employed and corporate employees, the remaining inequities seem relatively minor and not a sound basis for opposition to the bill. What is important is that H.R. Io would reduce the inequality of present law. An overall evaluation of H.R. Io as amended will show that it is a salutary step in the direction of tax equity. Present budgetary demands may permit no more than this. In two respects, the bill points the way toward future improvement of the entire tax treatment of retirement provision. 


\section{(5) Self-Help for the Self-Employed}

After ten years of unsuccessful legislative activity, the professional class of self-employed persons has undertaken, with the cooperation of seventeen state legislatures, to help itself to a qualified plan. ${ }^{63}$ The key difficulty has been that neither a sole proprietor nor a partner is an "employee" for purposes of the tax law. This fact has rendered unattainable not only qualified pension and profit sharing plans, but also a small host of less significant but nonetheless substantial tax advantages, especially:

r. Employee death benefits. Section IOI(b). By analogy to the exclusion of life insurance, the Code assures nontaxability for $\$ 5,000$ paid to an employee's survivors.

2. Deductible premium on group term life insurance. ${ }^{64}$

3. Sick pay exclusion. Section ro5(d).

4. Exempt lodging furnished for the convenience of the employer. Section irg. 5. Medical expense. Section 105(b). The medical expenses of an employee, his spouse, and his dependents paid by a corporate employer are deductible by the corporation and are yet not income to the employee.

6. Employee stock options. Section 42r. Promising executive talent could be given an opportunity to purchase a proprietary interest in the employer corporation at a price which is advantageous when the option is exercised, without the employee being taxed on the bargain purchase.

Montana's most notable tourist attraction to itinerant professional men would probably be Dr. Kintner's medical clinic in Missoula, which in 1954 was held to constitute a corporation for purposes of the federal income tax, whose memberpractitioners were "employees" of the entity. The Ninth Circuit upheld deduction of contributions to a qualified pension plan. ${ }^{65}$

At first, the Internal Revenue Service was reluctant to approve this result because of its understandable hesitancy to "open the flood gates." Besides, H.R. Io was being considered throughout the last ten years, and its possible enactment would relieve some of the pressure on the "professional association" route to tax equity. Another federal court, apparently not cognizant of the Kintner case, reached the

${ }^{{ }^{3}}$ Eber, The Pros and Cons of the New Professional Service Corporations, 15 J. Taxatron 308 (I96r); Jones, The Professional Corporation, 27 FordhaM L. REv. 353 (1958); Lyon, Action in Indiana on Kintner-Type Organizations, 39 TAxes 266 (196r); Maier, Don't Confuse Kintner-Type Associations with New Professional Corporations, I5 J. TAxation 248 (196I); Ray, Corporate Tax Treatment of Medical Clinics Organized as Associations, 39 TAXes 73 (I96r); Stutsman, How to Organize Professional Men for Corporate Tax Status Under Kintner, xI J. TAxution 336 (I959); Wolfman \& Price, Qualifying Under Final Kintner Rules Will Be Difficult in Most States, I4 J. Taxation I05 (196r). Bittker, Professional Associations and Federal Income Taxation: Some Questions and Comments, I7 TAX L. Rev. I (196r), abstracted in $16 \mathrm{~J}$. TAxation 238 (1962); Kahn, The Wisconsin Service Corporation Law of 1961, 1962 Wis. L. Rev. 65; Note, Professional Corporations and Associations, 75 HARv. L. Rev. 776 (I962); Plate, Professional Associations in Ohio, 3I U. Cinc. L. Rev. 7I (1962).

et Income Tax Regulations $\$$ I.6I-2(d)(2) (1957). See Rev. Rul. 54-165, 1954-I Cum. But.L. I7.

$\approx$ United States v. Kintner, 2I6 F.2d $4 \times 8$ (9th Cir. 1954). 
same result under Texas law. ${ }^{66}$ Then six years after the Kintner case, the "Kintner Regulations"BT were promulgated in final form. Under these regulations, the Treasury applies six criteria to determine whether an organization "more nearly resembles" a corporation than a partnership or trust:

I. Associates,

2. An objective to carry on business and divide the gains therefrom,

3. Continuity of life,

4. Centralization of management,

5. Limitation of liability for corporate debts to corporate property,

6. Free transferability of interests.

State law determines whether these characteristics inhere in a particular organization. The regulations indicate that since ( $I$ ) associates and (2) a business purpose are common to partnerships and corporations, they are indispensable requirements for corporate status. Apparently a preponderance of the remaining four characteristics-i.e., more than two-will carry the day the corporate way.

In those states which have enacted either the Uniform Partnership Act or the Uniform Limited Partnership Act, it may be difficult to attain corporate status. In Ohio and perhaps some other states the "Limited Partnership Association Act" may provide the required corporate attributes. ${ }^{68}$ By the end of March I962, seventeen states had enacted legislation authorizing the formation of what may be called "professional associations" or "professional corporations," which are designed to thwart legal (and perhaps ethical) obstacles and concurrently satisfy the Kintner regulations. ${ }^{69}$

Many unresolved problems stand between the eager professional man and his qualified plan even in these seventeen states. Some problems are common to several states, such as the one-man "association." Contradictory as the phrase appears, the Ohio Act specifically authorizes such organizations, ${ }^{70}$ and precedent is not

${ }^{\infty}$ Galt v. United States, I75 F. Supp. 360 (D. Tex. 1959).

or Treas. Regs. $\S 301.7701-1$ and -2 (1960), promulgated as T.D. 6503, Nov. 13, 1960, 25 Fed. Reg. $\operatorname{rog} 28$ ( 1960$)$.

${ }^{60}$ OHIO REv. CODE $\$ \mathrm{I}_{7} 83.0 \mathrm{r}$ et seq. (1961 Supp.)

${ }^{\infty} \mathrm{CCH} 196 \mathrm{I}$ STAND. FED. TAX REP. contains the text of all the following laws, at the paragraph numbers indicated in parentheses:

Alabama, H. 138, Act No. 865 (para. 6526)

Arkansas, Act. 179, 471 (paras. 6421, 6422)

Connecticut, $\$ 44$, Uniform Partnership Law (para. 6444)

Florida, H.B. 2I6I (para. 6423) Oklahoma, S.B. No. 399 (para. 6476)

Georgia, Act 285 (para. 6424) Pennsylvania, S.B. 525 (para. 6492)

Illinois, S.B. 804 (para. 6496) South Dakota, H.B. 689 (para. 6426)

Minnesota, S.F. No. 42X (para. 6425) Tennessee, ch. I8I (para. 6427)

Ohio, S.B. 550 (para. 6459) Wisconsin, ch. 350 (para. 6498)

See also a recent amendment to the Texas Uniform Partnership Law, CCH I96I STANd. Fed. TAx REP. para. 6578 .

In March, 1962, four more states enacted laws. See CCH 1962 Stand. Fed. TAx Rep. They are the following:

Arizona, S.B. No. 185 (para. 6353)

Kentucky, H.B. No. 97 (para. 6355)

South Carolina, H. 2154 (para. 6354)

${ }^{70}$ OHo Rev. COde $\S$ I785.02 (I96r Supp.). 
entirely lacking-consider the familiar close-held corporation all of whose stock is owned by a single individual. Particular local problems may arise under the variant wording of these state laws. For example, does the Ohio statute create a "corporation" for all purposes of the Ohio law? The Act denominates the organization an "association," but uses the word corporation or incorporation in six places. Cross reference is made to the General Corporation Code, and it is provided that all provisions of Ohio corporate law, except those specifically rendered inoperative by the Professional Association Act itself, apply fully to these organizations. It has been urged that if the state law creates a "corporation" in the ordinary sense, then its treatment for federal tax purposes follows automatically, and compliance with the Kintner regulations is unnecessary. ${ }^{71}$ In this writer's opinion, the mere labeling for state law would not control for federal tax purposes. However, if the substantive rules of state corporation law with all resulting characteristics apply to an organization, more than semantics is involved. This may be the true effect of the Ohio statute. ${ }^{72}$ Thus we are brought back to a careful inventory of corporate characteristics, taking into account the entire law of the state, and not merely the Professional Association Act itself. Some characteristics not mentioned in the Kintner regulations may be important to the ultimate characterization.

Perhaps the pendency of H.R. Io and quite probably the Administration's current study of long range tax reform, have contributed to the Commissioner's continued reluctance to embrace the new creature in the legal entity menagerie. District Directors have been denied authority to rule favorably on Kintner Klinics and must either deny approval or forward the request to the National Office for initial and final decision. ${ }^{73}$ It is apparent that particular scrutiny will be given to the reality and bona fides of the putative employment relationship, a question which is related to but distinct from the viability of the entity. ${ }^{74}$

The situation today is reminiscent of early 1948 when at least seven common law states had adopted or were about to adopt the Community Property System, entirely unsuited to their tradition and experience, solely to attain the benefits of income splitting. ${ }^{75}$ Just as President Truman vetoed the marital deduction and income splitting proposal in 1948, speculation has envisaged similar action by President Kennedy if Congress should pass H.R. ro. If the parallel is sound, history

${ }^{71}$ Maier, sapra note 63 . But see Bittker, supra note 63 .

${ }^{73}$ Consider Bulletin No. I6I from the Ohio Tax Commissioner to All County Auditors, Aug. I5, I96I. $22 \mathrm{CCH}$ STATE TAX Rev. No. 39 (Sept. 25, 196r): associations are corporations for all state tax purposes. In State ex rel. Green v. Brown, I73 Ohio St. II4, r8o N.E.2d I57 (1962), mandamus was sought to compel the Secretary of State to accept articles of incorporation of professional association of lawyers. Held, writ denied. The court stated that Rule XIV of the Supreme Court Rules of Practice prevents "the formation of a corporation to engage in the practice of law. ..." On the other hand, consider Oнго Const. art. XIII, $\S 3$, which precludes modification of the usual limited liability of corporate sharcholders. Hence the professional association must be presumed to be other than a corporation in order to preserve its constitutionality. See Brock, Taxes-Professional Associations-Not Permissible for Lawyers Under Present Ohio Court Rules, 31 U. Cinc. L. Rev. - (I962).

${ }^{73}$ Rev. Pro. 6I-II, I.R.B. I96I-18, p. 53 (May 1, 196I).

Ibid.

to Boris I. Bittker, Federal Income, Estate and Gift Taxation 280 n.2 (1958). 
suggests the possibility that the veto would be overridden as in I948. A factor of gxeat importance is the Administration's current study of long range tax reform, which will comprehend the demand for tax equity on the part of the self-employed from a perspective which can survey the overall problem of the taxation of retirement provision.

\section{II}

\section{A Proposed Tax Treatment for Retirement Provision}

There are strong indications that the taxation of retirement provision will receive thorough study and may undergo radical surgery as a result of the Treasury Department's current study of long range tax reform. There is prospect of a more integrated approach than has heretofore been taken. The question is always open academically, and may before long become open politically: How should retirement provision be taxed?

A significant contribution to the discussion of this question is contained in the work of Macaulay. ${ }^{76} \mathrm{He}$ proposes a new three-fold classification of retirement arrangements:

I. Vested refundable. The retirement income is assured whether the employee remains with the particular employer or not (vested). Furthermore, if the employee should die before retirement, his estate or named beneficiaries will be entitled to receive a death benefit equal to the contributions made by the employee and by his employer on his behalf. An employee might also be entitled to receive all contributions upon termination of his employment.

2. Vested non-refundable. The employee will receive benefits only if he lives to retirement age (non-refundable). However, the rights to retirement income do not depend on remaining with the particular employer (vested).

3. Non-vested. Not only must the employee live until retirement in order to receive any benefits, but also he must remain with the particular employer.

Macaulay then proposes the following tax treatment:

(I) Vested Refundable. Equating such a plan to a savings account with restrictions on withdrawal, he would make employer contributions taxable to the employee when made. Earnings on the portion of the fund attributable to each employee would be currently taxable as well. Benefits when received would be taxable under the annuity rule, with an exclusion ratio based on amounts previously taxed.

(2) Vested Non-refundable. Considering the contributions to such a plan as premiums for pure income insurance, the employer's portion should be excludable from the employee's income, and the employee's contributions should be deductible. Benefits would be taxable when received, with no investment recovery exclusion.

(3) Non-vested. Because receipt of retirement benefits is contingent upon remaining with the particular employer, as well as upon living to retirement age,

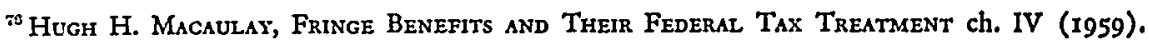


this sort of plan is too contingent to be characterized as pure income insurance. It constitutes some other kind of aleatory contract, bordering on a gambling arrangement. Since non-vested plans reduce the mobility of labor, they should be discouraged through disfavor under the tax law. (The favorable treatment proposed for vested non-refundable plans will encourage their adoption instead.) Therefore, the employer's contributions should be taxable to the employee at the time made. The earnings on the fund allocable to the particular employee should be currently taxed. Benefits would be taxable under the annuity rule when received, an exclusion ratio being allowed for contributions previously subjected to tax.

Macaulay makes no suggestion with reference to the tax treatment of the employer under any of the three types of plan.

This writer suggests a further distinction between the character of the annuity rights after retirement has been reached, and the nature of the employee's rights before retirement age. After retirement the plan may give (alternately to lump-sum distribution) (I) a straight single life annuity whose payments will cease upon the death of the annuitant however early this may occur, (2) a refundable annuity providing a minimum number of payments certain equal to the investment, or (3) an annuity providing a number of payments certain, still less than total investment. There may be a joint and survivor annuity, with any of the three arrangements as to payments after death of both annuitants. Furthermore, the plan might offer an "annuity" without life contingencies, such as a simple installment payment over ten or twenty years equaling the total contributions plus some agreed rate of interest. Finally, non-qualified deferred compensation contracts frequently provide contingent rights even during the pay-out period which would be forfeited if, for example, the former employee were to compete with his former employer. Any one of Macaulay's three types of plans, even including the non-vested type, might provide a refundable annuity once retirement age has been reached. While the nature of the employee's rights after retirement may determine appropriate tax treatment at that time, it should not necessarily control tax treatment during the working years.

Macaulay's classification and discussion seem to be directed mainly to the employee's rights during the working period. His elaborate analysis distinguishing the refundable savings type plan from other vested plans is a real contribution. However, it seems that defined operationally, a plan is "refundable" or not depending upon whether there are death benefits during the working period. A vested nonrefundable plan providing death benefits in any amount becomes pro tanto a vested refundable plan. If death benefits equal total contributions, then the plan is wholly refundable.

Is it not the case that we are dealing with two kinds of income insurance-retirement insurance (non-refundable plans) and life insurance (refundable plans)? Where death benefits amount to less than or more than total contributions, risk-spreading, the hallmark of life insurance, is more apparent. But even where death pay- 
ments are exactly equal to contributions, this portion of the aggregate of rights under the contract may be only a special form of increasing term life insurance. Many economists, perhaps representing the weight of professional opinion, hold that life insurance premiums, excepting that part which represents savings but including the administrative cost of spreading the risk, should be deductible as a cost of maintaining taxable income. ${ }^{77}$ Present law, of course, normally excludes from income the total amount of life insurance proceeds ${ }^{78}$ and precludes deduction of premiums, ${ }^{79}$ just the opposite of the income insurance approach of economists. If the portion of insurance premiums which represents the pure cost of income insurance plus the portion representing administrative expense were to become deductible, this would call for taxation of life insurance proceeds when received.

Retirement plans, like other forms of "property," represent a bundle of rights. Even the non-vested plan, shifting contributions and benefits from the less stable or more mobile worker to those who remain with the employer throughout their working lives, provides a kind of "term" retirement income insurance. A vested non-refundable plan simply offers a permanent policy of retirement insurance, not permitting forfeiture and consequent transfer of one's interest in the fund to another on termination of employment. Vested refundable plans, and any plans which include death benefits, combine retirement insurance with a certain amount of life insurance.

It is submitted that all three forms of retirement provision, with the possible exception of those which permit withdrawal of all contributions on termination of employment, are forms of income insurance-partly against the risk of retirement and partly against the risk of death-and hence should be deductible by the employee if made from cash income and excludable if made by an employer on an employee's behalf.

Corollary is the full taxability of all retirement benefits when received, and inclusion of life insurance proceeds in gross income as well. Since these forms of income insurance are also socially approved forms of income shifting, tax should be imposed on those who receive, not those who provide, the income. Shift the tax with the enjoyment. Provision could be made for the tax-free recovery of the non-deductible portion of life insurance premiums. The hardship of bunching could be relieved by permitting annuity elections that would postpone inclusion, or by a spreadback or averaging device. ${ }^{80}$ The proposal has the advantage that the income element in life insurance contracts, heretofore non-taxable, would return to the tax base. Although immediate revenues would probably be reduced, in the long run the tax base would be increased. While contributions to retirement plans and life insurance premiums ${ }^{81}$ would be eliminated from the base, all benefits would return to it in future years, compounded by the increment on the funds.

"7or example, William S. Vickrey, Agenda for Progressive Taxation 66 (1947).

${ }^{78}$ CODE $\$$ ror.

To Id. $\S \S 262,264$.

${ }^{50}$ The "5 times the tax on $1 / 5$ the income" rule of H.R. Io has much to recommend it.

s1 The savings portion of life insurance premium-approximately the difference between ordinary life and term-would be nondeductible. Basis would be the nondeductible portion of premium, and only the excess would be taxable when proceeds were received. 
The proposed treatment of retirement provision necessarily permits unlimited deferral. Serious revenue problems resulting from this could be controlled by placing a dollar limitation on total contributions for all retirement arrangements, for the self-employed or the corporate employee. Over a long term of years these limitations could be relieved as deferred income, enhanced by its increment, returns to the tax base in ever-increasing amounts.

The key fiscal tool for influencing employer behavior is of course control of the employer deduction. It is assured current deductibility, more than anything else, which renders an employer willing to incur the cost of providing retirement benefits on a broad scale. Deferral for management employees provides an added incentive, but cannot in itself induce the large financial undertaking which adoption of a plan entails. The salutary policy of encouraging diffusion of retirement benefits among the entire working population could be furthered by continuing to limit favorable treatment to qualified plans, although requirements for qualification -applicable alike to self-employed and corporate employees-could be tightened up. The trend toward vested plans could be encouraged by extending future qualification (as does H.R. Io) only to plans which provide for early vesting, thereby enhancing the mobility of labor.

Consistently with the proposed treatment of private retirement plans, Social Security contributions made by employers should continue non-taxable. The employee's contributions should become deductible. Any dollar limitation on total retirement provision might take into account amounts contributed to Social Security. Contributions to the Social Security fund made by the self-employed should be fully deductible. All benefits would be taxable when received. No great hardship on low income persons would result since exemptions are doubled after age $6_{5}$ and the present exemption of Social Security is in many cases an unnecessary duplication.

If budgetary considerations require, as they probably will, the imposition of dollar limitations on total retirement provision, the pressure on non-qualified plans will increase radically. It seems probable that an integrated treatment of retirement provision must set limitations on non-qualified plans. Either tax disfavor must eliminate them-directing all deferred compensation into the qualified category-or at least statutory rules governing the extent of and requirements for deferral and deduction must be evolved. This is probably unfinished business, begun by section 23(p) of the 1939 Code as enacted in 1942 (now section 404(a)).

Of course, the practical urgency behind the drive for deferral stems from a felt common need for relief from the high surtax brackets. The integrity of a graduated tax structure would not be undermined by a provision for lifetime averaging, whatever its administrative feasibility ${ }^{82}$ To a large extent, the interest in deferred

\footnotetext{
2 Henry C. Simons, Personal Income Taxation I54 (1938); Vickrey, op. cit. supra note 77, at 172-97; Pechman, A Practical Averaging Proposal, 7 NAT'L TAX J. 26I (I954); Maxwell, Averaging Fluctuating Income of the Individual for Income Tax Purposes, 20 Accounting Rev. 85 (r945); Steger, On the Theoretical Equity of An Averaging Concept for Income Tax Purposes, I3 TAX L. REv. 2II
} 
compensation of all types derives from the desire to achieve pro tanto the benefits of lifetime averaging. It may be said that permitted deferral is a piece-meal approach to the need for averaging, but until an equitable and administratively feasible system of lifetime averaging has been evolved, there is considerable reason for retaining and expanding this area of permitted averaging. The advantage of the present approach, proposed to be expanded to cover all taxpayers subject alike to common limitations, is that it places a tax incentive behind the extremely valuable social goal of wide scale voluntary provision for retirement. In a sense, retirement provision is long-range saving. It is distinct from ordinary saving in the limitations on withdrawal and the resulting equity in deferral. The economic impact of the growth of pension plans is a subject of great interest and concern. ${ }^{83}$ It cannot help but have the effect of increasing the amount of economic wealth available for investment in productive enterprise. On grounds of equity, reconcilable with varying budgetary demands, not inconsistent with the graduated tax structure, and in the name of economic growth, the foregoing proposal is submitted.

(1958); see also Steger, Averaging Income for Tax Purposes: A Statistical Study, 9 NAT'L TAx J. 97 (1956); Steger, Life-time Income Averaging: What It Means for the Professional, i2 TAx L. Rev. 427 (1957).

Present tax law abounds with special limited averaging provisions, varying widely in their approach:

(a) Net Operating Loss Carryover, CODE $\$$ I72; (b) Capital Loss Carryover, Code $\$$ I212; (c) Compensation for a Long-Range Project, CODE 1301; (d) Damages for Patent Infringement, Code $\$$ 1304; (e) Income from an Invention or Artistic Work, CoDE \$ 1302; (f) Back Pay, CODE \$ I303; (g) Damages for Breach of Contract, CODE $\$$ 1305; (h) Restoration of Amounts Received under a Claim of Right, CoDE § 134I; (i) Throwback of Excess Distributions of Trust Income, Cope \$ 668(a); (j) Surrender of a Life Insurance or Annuity Contract, Cone $\$ 72(c)(3)$; (k) Installment Method, CODE $\$ 453$; (l) Tax Benefit Rule, Cope $\S$ IIx; (m) Long-Term Capital Gains Treatment in General, CODE $\$ \$$ I20I, 1202; (n) Corporate accumulation at flat rate and dividend distribution timed to produce averaging; (o) similar practice with discretionary trusts.

${ }^{8}$ Paul P. Harbrecht, Pension Funds and Economic Power (1959). The rise of pension plans is correlated with the problem of mandatory retirement. Sec Rrchard A. \& J. W. Tower, Execurrve Retirement and Effective Management (Ig6r). 